\title{
Trace elements in an adjacent channel of an anthropized area: a case study of Baixada Santista, Southeastern Brazil
}

\author{
Salaroli, A.B.; Kim, B.S.M.; Angeli, J.L.F. \& Figueira, R.C.L. \\ Instituto Oceanográfico, Universidade de São Paulo (IO-USP). Adress: Pça. do Oceanográfico, 191, \\ Butantã, São Paulo, Brasil. Zip Code: 05508 120. Phone: +55 1130917182.
}

Received October 25, 2017; Accept February 05, 2018

\begin{abstract}
In recent decades, due to intensive industrialization, the Baixada Santista has undergone an intense process of environmental degradation. The metals are toxic and persistent in varying concentrations and oxidation states and may be incorporated in sediments and biota. Thus, understanding the importance of this contamination is necessary for coastal planning. This study provides a basis for understanding the levels of metal and As contamination in the Bertioga Channel (SP). The levels of Al, $\mathrm{As}, \mathrm{Cd}, \mathrm{Cr}, \mathrm{Cu}, \mathrm{Fe}, \mathrm{Mn}, \mathrm{Ni}, \mathrm{Pb}, \mathrm{Sc}, \mathrm{V}$ and $\mathrm{Zn}$ in superficial sediment samples were determined by ICP-OES. The degree of sediment contamination was evaluated according to the sediment quality standards set by the Canadian environmental agency (ISQG and PEL) and by statistical tests. All values were below PEL, and most of the sample values were below ISQG, except for $\mathrm{As}, \mathrm{Cu}$ and $\mathrm{Pb}$. From a cluster analysis, it was possible to differentiate eastern and western parts of the channel due to their distinct hydrodynamic patterns. Furthermore, it was possible to separate the trace elements by geochemical behavior, in which $\mathrm{Cu}, \mathrm{Pb}$ and $\mathrm{Zn}$ were linked to a small anthropogenic contribution. Thus, this study detected small anthropogenic contributions from an adjacent channel of an anthropized area, but most of the results were linked to natural geochemical processes.
\end{abstract}

Key words: Trace elements. Sediment. ICP-OES. Santos Estuary

\section{INTRODUCTION}

Trace element contamination in the marine environment has received increasing attention worldwide due to its persistence, toxicity depending on the oxidation state, nonbiodegradable nature and ability to bioaccumulate and biomagnify (Abdallah, 2008; Islam et al., 2015). Like other elements, trace elements exist at natural levels in the earth's crust derived from shales, sandstones, metamorphic and igneous rocks, as well as pollutants from human activity. Some are considered essential micronutrients, while others do not possess known biological function and, depending on the oxidation state, present extreme toxicity, necessitating the monitoring of aquatic environments (Karedede-Akin \& Ünlü, 2007). Thus, sediment has been widely used as an environmental quality indicators (e.g., Bordon et al., 2011; Buruaem et al., 2013; Kim et al., 2017).
Considered one of the most important regions of the coastal zone, estuaries are among the most productive ecosystems in the world, having great ecological, economic and social importance. Estuaries are capable of retaining pollutants due to their high geochemical reactivity, and they are potential scavengers of suspended particulate material, facilitating the deposition of sediment and its associated contaminants, thus preventing export to the adjacent shelf (Baptista Neto et al., 2004) and allowing estuaries to act as geochemical barriers (Kjerfve \& Magill, 1989). The direct or indirect introduction of substances by humans can reach high concentration, causing contamination of estuarine waters with harmful effects to the living resources and danger to human health, among other effects (Miranda et al., 2002).

The Estuarine System of Santos and São Vicente is considered one of the most economically important regions of Brazil. Due to its strategic location, it harbors one of the largest 
ports in Latin America, the Port of Santos, being the 39th busiest port in the world, exceeding one million containers per year (CODESP, 2011), as well as the country's most important industrial complex, the Complex of Cubatão, with approximately 1,100 industries (CBH-BS, 2011). An important segment of the Estuarine Complex of Baixada Santista is its northern portion, called the Bertioga Channel which connects the High Estuary directly to the ocean by an inlet located near the Bertioga city. This segment of the estuary has the most structurally developed mangrove areas (Schaeffer-Novelli, 1984) and represent an area with potential retention of anthropogenic substances. Although the channel is adjacent to a highly anthropized region, it is still considered a pristine environment (Gonçalves et al., 2013).

To assess the compatibility of exploitation and protection of coastal ecosystems, it is important to qualify and quantify the impacts of anthropogenic activities not only in hot spots but also in the surrounding areas to quantify the extent of the contamination. Thus, this study aims to determine the levels of metals and As in surface sediments of the Bertioga Channel (SP).

\section{MATERIAL AND METHODS}

The Bertioga Channel, which is part of the Estuarine Complex of Santos and São Vicente, is located between latitudes $23^{\circ} 51^{\prime} \mathrm{S}$ and $23^{\circ} 57^{\prime} \mathrm{S}$ and longitudes $46^{\circ} 08^{\prime} \mathrm{W}$ and $46^{\circ} 19^{\prime} \mathrm{W}$, and comprises a total area of approximately 51,500 ha. It extends $25 \mathrm{~km}$, with average depth between 3 and 6 $\mathrm{m}$. It is considered a secondary connection of the ocean to the Estuarine Complex of Santos, with its northeast inlet located near the city of Bertioga, and the opposite inlet near the channel of the High Estuary.

In 2011, 127 surface sediment samples were collected in the Bertioga Channel and 20 samples were collected in the Itapanhaú River with a Van Veen bottom sampler (Figure 1). The samples were lyophilized and homogenized for analysis. Digestion of samples was performed by acid leaching using the USEPA 3050b method (USEPA, 1996). It is important to mention that this method involves a strong acid digestion that dissolves the "environmentally available" elements, excluding those bound in silicate structures, which are not usually mobile in the environment. Determination of $\mathrm{Al}, \mathrm{As}, \mathrm{Cd}, \mathrm{Cr}, \mathrm{Cu}$, $\mathrm{Fe}, \mathrm{Mn}, \mathrm{Ni}, \mathrm{Pb}, \mathrm{Sc}, \mathrm{V}$ and $\mathrm{Zn}$ was performed by inductively coupled plasma optical emission spectrometry (ICP-OES) using the SW-846 US EPA 6010c method (USEPA, 2007).

Two certified reference materials (CRM) of contaminated soil, SS-1 and SS2 (EnviroMAT Contaminated Soil from SCP Science), were subjected to the same method of extraction (US EPA 3050b) to analytical quality controls. All results were within the range recommended by USEPA (1996) between $75 \%$ and $125 \%$. Table 1 shows the results obtained for the recovery percentages of the reference materials, SS-1 and SS-2 $(\mathrm{n}=7)$.

Since the grain size directly influences metal content and characterization of the sedimentary organic matter, the percentage of the fine fraction (mud) was determined through wet sieving using a $0.063 \mathrm{~mm}$ mesh sieve. The calcium carbonate content $\left(\mathrm{CaCO}_{3}\right)$ was determined by adding $\mathrm{HCl}$ to the samples until effervescence ceased. Thereafter, the solution was diluted with deionized water, centrifuged, and the supernatant was removed. This washing procedure was repeated at least three times for each sample. The sediment was then dried and weighed, and carbonate content was calculated by difference between the weight before and after carbonate removal. Total organic carbon (TOC) analyses were performed using an EA Costech elemental analyser coupled with a Finnigan Delta V Plus isotopic ratio mass spectrometer (IRMS).

\section{RESULTS AND DISCUSSION}

In general, sand content (coarse fraction $>0.063 \mathrm{~mm}$ ) predominated over the fine fraction in the eastern part of the channel in the inlet next to the city of Bertioga (Figure 2), due to strong influence of tidal currents in this region, which favor the deposition of coarser sediments. In the central region of the channel (Largo do Candinho), a higher percentage of fine sediments was verified, with values greater than $90 \%$ where the influence of tidal currents was not verified thus favoring the sedimentation of finer particles.

Trace element concentrations in the surface sediments of the Bertioga Channel are presented in Table 2 and Figure 2. The As concentrations ranged from 0.46 to $14.74 \mathrm{mg} \mathrm{kg}^{-1}$, and the mean value \pm standard deviation was $7.48 \pm 3.15 \mathrm{mg} \mathrm{kg}^{-1}$. Higher values were observed near the city of Bertioga and in the middle of the channel, which was a different pattern than for the other analyzed elements. In general, concentrations of $\mathrm{Al}, \mathrm{Cr}, \mathrm{Fe}, \mathrm{Mn}, \mathrm{Ni}, \mathrm{Sc}, \mathrm{V}$ and $\mathrm{Zn}$ presented similar spatial distribution patterns, with the lowest values found in the eastern part of the channel adjacent to the Atlantic Ocean. The highest concentrations were observed from Largo do Candinho up to the Santos channel (western portion of the study area). For $\mathrm{Cu}$ and $\mathrm{Pb}$, the highest values were found near Santos, with decreasing values towards the city of Bertioga.

In this study, a more in-depth evaluation was performed for the elements $\mathrm{As}, \mathrm{Cr}, \mathrm{Cu}, \mathrm{Ni}, \mathrm{Pb}$ and $\mathrm{Zn}$, because among these, $\mathrm{Cu}$ and $\mathrm{Zn}$ are essential for the metabolism of organisms but are toxic at high concentration and oxidation states while

Table 1. Recovery values for the Certified reference materials (CRM) and method limit detection (MDL)

\begin{tabular}{lccccc}
\hline Element & CRM & $\begin{array}{c}\text { Certified } \\
\text { IC }(\mathrm{mg} \\
\left.\mathrm{kg}^{-1}\right)\end{array}$ & $\begin{array}{c}\mathrm{IC}(\mathrm{mg} \\
\left.\mathrm{kg}^{-1}\right)\end{array}$ & $\begin{array}{c}\text { Recovery } \\
(\%)\end{array}$ & $\begin{array}{c}\mathrm{MDL} \\
\left(\mathrm{mg} \mathrm{kg}^{-1}\right)\end{array}$ \\
\hline $\mathrm{As}$ & $\mathrm{SS}-1$ & $17-19$ & $16-18$ & 99.55 & 0.40 \\
$\mathrm{Cd}$ & $\mathrm{SS}-2$ & $65-85$ & $73-80$ & 99.47 & \\
$\mathrm{Cr}$ & $\mathrm{SS}-2$ & - & $2-2$ & 102.75 & 0.7 \\
$\mathrm{Cu}$ & $\mathrm{SS}-1$ & $55-73$ & $60-80$ & 95.14 & 0.09 \\
$\mathrm{Ni}$ & $\mathrm{SS}-2$ & $30-38$ & $32-33$ & 93.52 & \\
$\mathrm{~Pb}$ & $\mathrm{SS}-2$ & $182-200$ & $185-193$ & 97.22 & 0.14 \\
$\mathrm{Zn}$ & $\mathrm{SS}-2$ & $50-58$ & $54-55$ & 91.66 & 0.18 \\
& $\mathrm{SS}-2$ & $116-136$ & $123-129$ & 83.03 & 0.29 \\
& $\mathrm{SS}-2$ & $444-490$ & $454-490$ & 94.11 & 0.29 \\
\hline
\end{tabular}



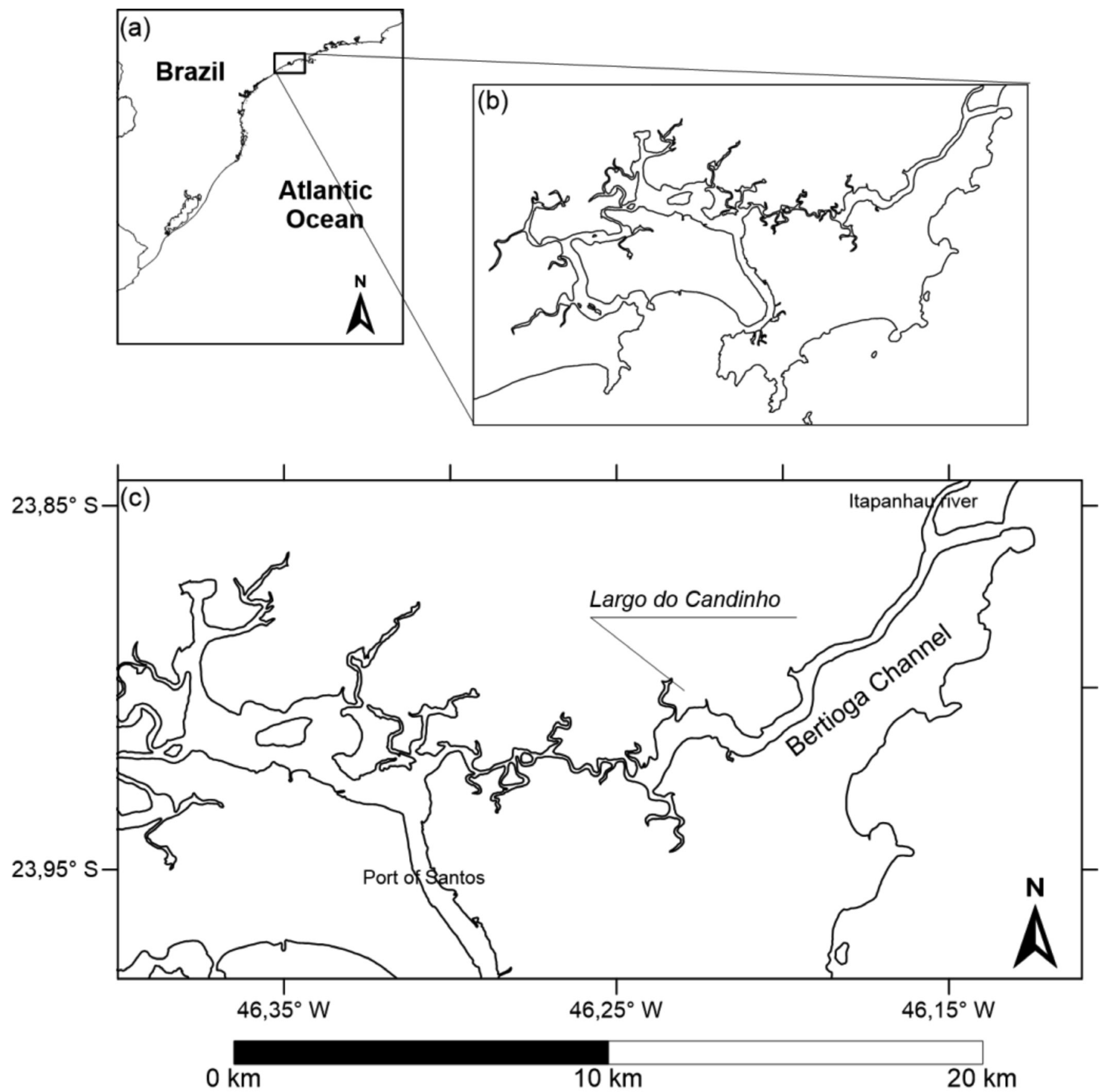

Figure 1. Location of the Bertioga Channel and sampling points. (a) Southeastern Brazil; (b) Baixada Santista; and (c) Bertioga Channel.

the others are potentially toxic even at low concentrations (Karadede-Akin \& Ünlü, 2007). Thus, they are the most assessed elements in contamination studies (e.g., Kim et al., 2016; Tramonte et al., 2016; Goher et al., 2014)

Apart from $\mathrm{As}, \mathrm{Cu}$ and $\mathrm{Pb}$, most of the samples had low measurements, for which adverse effects to the biota are rarely expected, indicating minimal to no contamination. With respect to As, 80 samples (54\%) had values above the ISQG (Interim Sediment Quality Guideline) (CCME, 2001). These sample sites were near the city of Bertioga, reaching up the Santos Estuary. Normally, this element occurs in the majority of rocks in concentrations that can reach $13 \mathrm{mg} \mathrm{kg}^{-1}$ in clayish sediments (CETESB, 2001). In general, As is present in the environment associated with deposits of metallic minerals and its main sources are related to the extraction and processing of these minerals, production of pigments, wood preservatives, pesticides and glass industry (Reimann et al., 2009). There are no specific industrial sources of this pollutant in the Santos estuarine region (CETESB, 2001), which suggests that the higher concentrations were not directly related to anthropogenic actions. In addition, there are several studies that report high As values in Brazil (e.g. Costa et al., 2016; Kim et al., 2016; 2018) which further suggests that the high values in the present study may have been from natural processes.

Copper concentrations were above ISQG levels in 7 samples (approximately 5\%) located in the western part of 

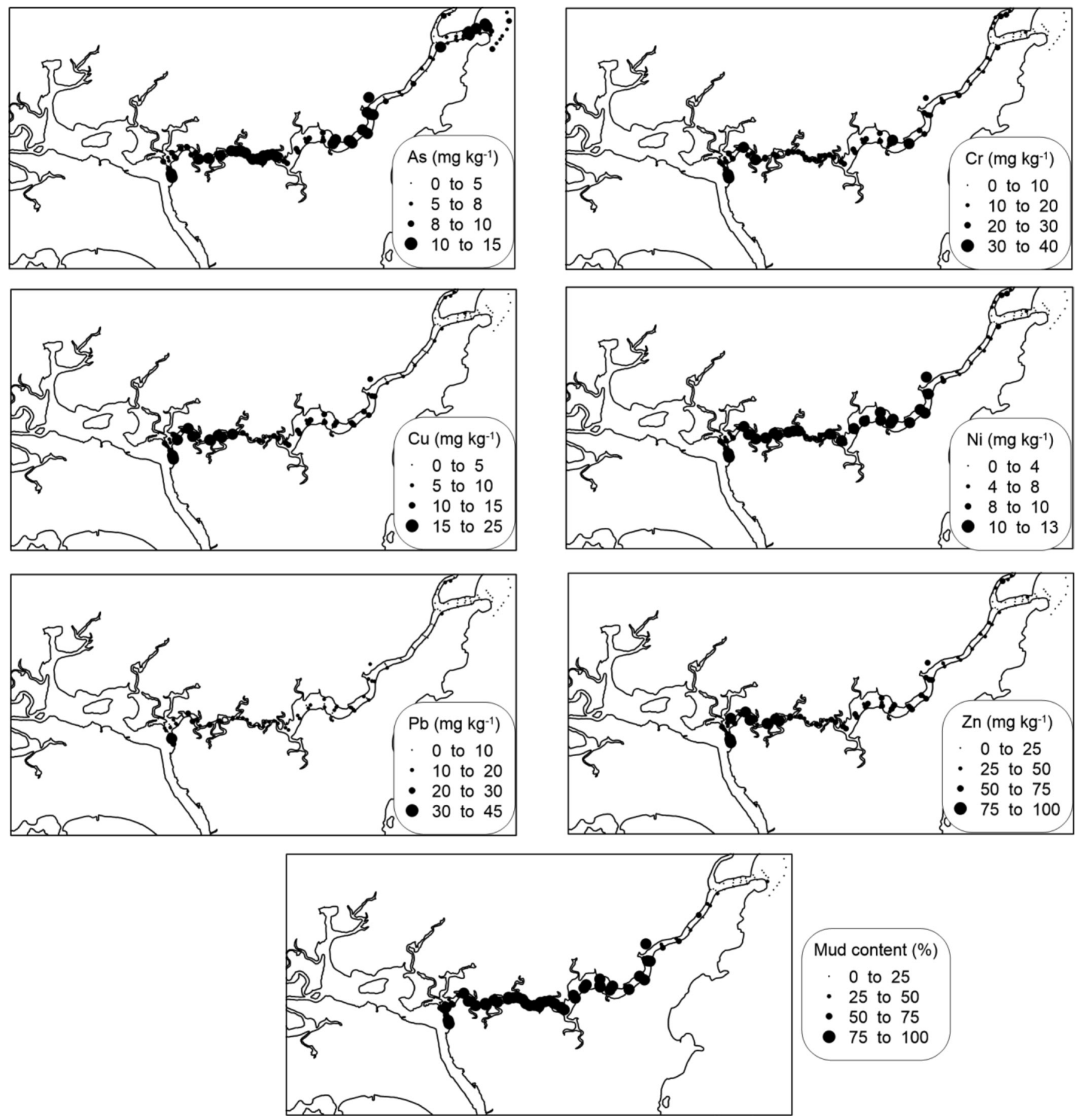

Figure 2. Spatial distribution of trace elements and mud content at Bertioga Channel.

the channel near the Santos Channel. This element has a wide distribution in earth's crust, and in general, is considered a ubiquitous element since it is a metal of wide industrial and domestic use. According to CETESB (2001), in the Baixada Santista, copper has been detected in the effluent from several industries in the Industrial Complex and from some port terminals, and is also present in landfills and untreated sewage that is directly discharged to the sea and estuary.

Only one sampleshad $\mathrm{Pb}$ concentrations above the ISQG, it was from a site near the city of Santos. This element is generally associated with $\mathrm{Pb}$ ore extraction, processing and smelting, and it is normally found as a contaminant in waste from the production of steel and petrochemicals. $\mathrm{Pb}$ is considered a contaminant since its inorganic compound has carcinogenic effects and could cause behavioral disturbances in vertebrates (Jakimska et al., 2011). The high $\mathrm{Pb}$ level found in this study may be related to industrial activities in Baixada Santista and discharged to the Bertioga Channel by the tides, but there is only one sample with a high $\mathrm{Pb}$ level, and this may be considered an atypical value.

To evaluate the metal concentrations found in the Bertioga Channel, Table 3 present a comparison of metal and As levels 
Table 2. Mean \pm standard deviation (SD) and concentration range of trace elements in surface sediments of the Bertioga Channel, and ISQG and PEL from sediment quality guidance (CCME, 2001).

\begin{tabular}{lccccc}
\hline Element & $\begin{array}{c}\text { Mean } \pm \text { SD }(\mathrm{mg} \\
\left.\mathrm{kg}^{-1}\right)\end{array}$ & $\begin{array}{c}\text { Minimum } \\
\left(\mathrm{mg} \mathrm{kg}^{-1}\right)\end{array}$ & $\begin{array}{c}\text { Maximum } \\
\left(\mathrm{mg} \mathrm{kg}^{-1}\right)\end{array}$ & $\begin{array}{c}\text { ISQG } \\
\left(\mathrm{mg} \mathrm{kg}^{-1}\right)\end{array}$ & $\begin{array}{c}\text { PEL } \\
\left(\mathrm{mg} \mathrm{kg}^{-1}\right)\end{array}$ \\
\hline $\mathrm{As}$ & $7.94 \pm 2.80$ & 0.46 & 14.74 & 7.24 & 41.6 \\
$\mathrm{Al}$ & $14225.3 \pm$ & & & & \\
& 9006.82 & 2305.14 & 3833.30 & & \\
$\mathrm{Cd}$ & $<\mathrm{MDL}$ & $<\mathrm{MDL}$ & $<\mathrm{MDL}$ & 0.7 & 4.2 \\
$\mathrm{Cr}$ & $16.35 \pm 8.70$ & 3.14 & 33.13 & 52.3 & 160 \\
$\mathrm{Cu}$ & $7.43 \pm 5.51$ & 0.70 & 23.29 & 18.7 & 108 \\
$\mathrm{Fe}$ & $17193.05 \pm$ & & & & \\
& 8270.07 & 3348.12 & 33747.80 & & \\
$\mathrm{Mn}$ & $225.43 \pm 118.11$ & 37.90 & 630.04 & & \\
$\mathrm{Ni}$ & $6.37 \pm 3.53$ & 1.16 & 12.81 & & \\
$\mathrm{~Pb}$ & $10.15 \pm 6.49$ & 1.54 & 43.43 & 30.2 & 112 \\
$\mathrm{Sc}$ & $2.91 \pm 1.66$ & 0.53 & 5.87 & - & - \\
$\mathrm{V}$ & $20.47 \pm 9.62$ & 4.72 & 37.83 & - & - \\
$\mathrm{Zn}$ & $41.52 \pm 9.62$ & 7.45 & 94.39 & 124 & 271 \\
\hline
\end{tabular}

Table 3. Range of metal concentrations in different regions of Brazil.

\begin{tabular}{|c|c|c|c|c|c|c|}
\hline \multicolumn{7}{|c|}{ Metals (mg kg-1) } \\
\hline Study area & As & $\mathrm{Cr}$ & $\mathrm{Cu}$ & $\mathrm{Ni}$ & $\mathrm{Pb}$ & $\mathrm{Zn}$ \\
\hline Guanabara & & $<10.0$ & & $<10.0-$ & $<10.0$ & $<10.0-$ \\
\hline Bay $\mathrm{RJ}^{1}$ & & 9230 & $5.0-390$ & 1300 & 2290 & 31.0 \\
\hline Paranaguá & $0.59-$ & $2.44-$ & $0.55-$ & $2.46-$ & $0.25-$ & $1.65-$ \\
\hline $\mathrm{PR}^{2}$ & 21.7 & 69.5 & 15.8 & 36.9 & 37.6 & 76.2 \\
\hline Santos - S. & $0.10-$ & $<1.00-$ & $<0.10$ & $0.97-$ & $005-567$ & $5.20-$ \\
\hline Vicente $\mathrm{SP}^{3}$ & 20.8 & 106 & 167 & 57.0 & $0.05-56 /$ & 2600 \\
\hline RJ Coastal & & $130-385$ & $<0.01-$ & & $1.80-$ & $<0.01-$ \\
\hline shelf ${ }^{4}$ & - & $1.50-50.5$ & 11.2 & & 17.7 & 60.9 \\
\hline Cananéia - & & $9.74-$ & $<0.50-$ & $0.33-$ & $<0.40-$ & $15.5-$ \\
\hline $\mathrm{SP}^{5}$ & - & 21.5 & 14.0 & 1.65 & 26.0 & 42.4 \\
\hline Bertioga & $0.46-$ & $3.14-$ & $0.70-$ & $1.16-$ & $1.54-$ & $7.45-$ \\
\hline Channel(SP) & 14.74 & 33.13 & 23.29 & 12.81 & 43.43 & 94.39 \\
\hline
\end{tabular}

${ }^{1}$ Machado et al. (2002); ${ }^{2}$ Sá et al. (2006); ${ }^{3}$ Cesar et al. (2007); Oliveira et al. (2005); Choueri et al. (2010); ${ }^{4}$ Carvalho et al. (2005); ${ }^{5}$ Berber et al. (2007).

in the different environments of Brazil. The concentrations found by other authors in regions adjacent to this study, as well as in the Santos and São Vicente Estuary (Oliveira et al., 2005; Siqueira et al., 2005; Cesar et al., 2007; Choueri et al., 2010), based on the weight-of-evidence approach, provides a structure and a process for conducting sediment/ dredging material assessment that leads to a decision. The main structure consists of $\backslash$ "step 1।" (examination of available dataare much higher than those found in the Bertioga Channel. From the metal concentrations reported in the literature, it is seen that the results of this study do not represent anomalous values. Furthermore, the levels found are within the range of variation presented for the continental shelf region of SP and RJ (Carvalho et al., 2005). The levels in this study were also slightly high compared to a non-impacted region such as Cananéia (SP) (Berber et al., 2007), and much lower than in port regions such as Guanabara Bay (RJ) (Machado et al., 2002). These results suggest that potential contaminants are scavenged in the Santos and São Vicente estuarine system, which acts as a geochemical barrier that prevents the contamination of adjacent areas.

To verify correlations in the studied variables, we applied the Pearson correlation test. Table 4 show a matrix of the variables with their respective correlation coefficients (r). The matrix shows that all the results present a significant $(\alpha$ $=0.05)$ positive correlation $(\mathrm{r}>0)$. The variables that had relatively low correlations were As, $\mathrm{Mn}$, carbonate and total organic carbon. The highest correlations were for $\mathrm{Al}, \mathrm{Fe}, \mathrm{Cr}$, $\mathrm{Ni}, \mathrm{Sc}, \mathrm{V}$ and the fine fraction (mud) content. Al, Fe, Sc and V are considered proxies for particle size, as they are lithogenic and conservative (Elkady et al., 2015; Wang et al., 2015; Kim et al., 2017), and a high correlation is expected. However, high correlations for the other metals $(\mathrm{As}, \mathrm{Cu}, \mathrm{Cr}, \mathrm{Ni}, \mathrm{Pb}$ and $\mathrm{Zn}$ ) are further evidence of the absence of contamination since these elements vary with grain size.

A cluster analysis of the 147 samples (Figure 3) showed the presence of two large, distinct groups (A and B). In group A, $82 \%$ of the samples were from the eastern part of the channel. Group B represented $73 \%$ of the samples from the western part of the channel. This analysis showed that Largo do Candinho has the potential to be a maximum turbidity zone, with two groups of samples with different characteristics. One of the groups was from the region that is directly influenced by the tides, where deposition of sandy sediments prevails, and other group was from the region influenced by the channel of the Port of Santos. The confluence of channel waters and opposing tidal currents occurs in Largo do Candinho, where the influence of the tide is practically null and where muddy sediments are predominantly deposited (Fúlfaro \& Ponçano, 1976; Miranda \& Castro, 1991).

In Figure 4, the cluster analysis of the studied variables is presented, it also shows the presence of the two large groups. A group in which all elements, except $\mathrm{Mn}$ and As, correlate with fine sediment, is support for the direct effect of grain size on metal content, which is adsorbed on the fine particles that have more surface area for contact (Forstner \& Salomons, 1980; Fukue et al., 2006; Song et al., 2014).

In the cluster analysis, we observed three other small groups: the first, included $\mathrm{Cr}, \mathrm{Ni}, \mathrm{Sc}$ and $\mathrm{V}$, and had low concentrations and no anthropogenic contribution; the second, included the macroelements $\mathrm{Al}$ and $\mathrm{Fe}$ in high concentrations that represent natural levels; and finally, $\mathrm{Cu}, \mathrm{Pb}$ and $\mathrm{Zn}$, with the same geochemical behavior, could be linked to a small anthropogenic contribution but were still lower than the levels found by other authors, as cited above.

In the second group, arsenic levels were grouped with Mn, carbonate and total organic carbon. This finding could be explained by the fact that As had a different distribution pattern than the other elements, which were more concentrated in sandy sediments. Furthermore, As distribution can be explained by its adsorption on manganese oxides (Takamatsu et al., 1985) and its retention by carbonates (Romero et al., 2004; Reimann et al., 2009; Mirlean et al., 2012), besides being enriched in Brazilian rocks as some authors have found recently (Costa et al., 2016; Kim et al., 2018; Mirlean et al., 2012). 
Table 4. Correlation matrix for the studied variables in the Bertioga Channel

\begin{tabular}{lccccccccccccc}
\hline & $\mathrm{As}$ & $\mathrm{Al}$ & $\mathrm{Cr}$ & $\mathrm{Cu}$ & $\mathrm{Fe}$ & $\mathrm{Mn}$ & $\mathrm{Ni}$ & $\mathrm{Pb}$ & $\mathrm{Sc}$ & $\mathrm{V}$ & $\mathrm{Zn}$ & $\%$ mud & $\begin{array}{c}\text { \% } \\
\mathrm{CaCO} 3\end{array}$ \\
\hline $\mathrm{As}$ & & & & & & & & & & & & & \\
$\mathrm{Al}$ & 0.453 & & & & & & & & & & & \\
$\mathrm{Cr}$ & 0.667 & 0.890 & & & & & & & & & & \\
$\mathrm{Cu}$ & 0.479 & 0.752 & 0.855 & & & & & & & & & \\
$\mathrm{Fe}$ & 0.631 & 0.945 & 0.938 & 0.783 & & & & & & & & & \\
$\mathrm{Mn}$ & 0.766 & 0.681 & 0.799 & 0.618 & 0.778 & & & & & & & & \\
$\mathrm{Ni}$ & 0.654 & 0.892 & 0.988 & 0.862 & 0.931 & 0.787 & & & & & & \\
$\mathrm{~Pb}$ & 0.538 & 0.745 & 0.850 & 0.898 & 0.782 & 0.653 & 0.848 & & & & & \\
$\mathrm{Sc}$ & 0.603 & 0.936 & 0.979 & 0.841 & 0.940 & 0.780 & 0.978 & 0.828 & & & & \\
$\mathrm{~V}$ & 0.678 & 0.918 & 0966 & 0.817 & 0.944 & 0.800 & 0.958 & 0.813 & 0.977 & & & & \\
$\mathrm{Zn}$ & 0.546 & 0.830 & 0.907 & 0.965 & 0.861 & 0.699 & 0.920 & 0.910 & 0.905 & 0.889 & & & \\
\%mud & 0.584 & 0.852 & 0.953 & 0.833 & 0.902 & 0.714 & 0.953 & 0.800 & 0.947 & 0.905 & 0.872 & \\
\%CaCO3 & 0.425 & 0.470 & 0.555 & 0.535 & 0.525 & 0.423 & 0.542 & 0.492 & 0.531 & 0.496 & 0.536 & 0.611 \\
\% TOC & 0.544 & 0.652 & 0.734 & 0.592 & 0.730 & 0.502 & 0.752 & 0.576 & 0.724 & 0.704 & 0.641 & 0.818 & 0.542 \\
\hline
\end{tabular}

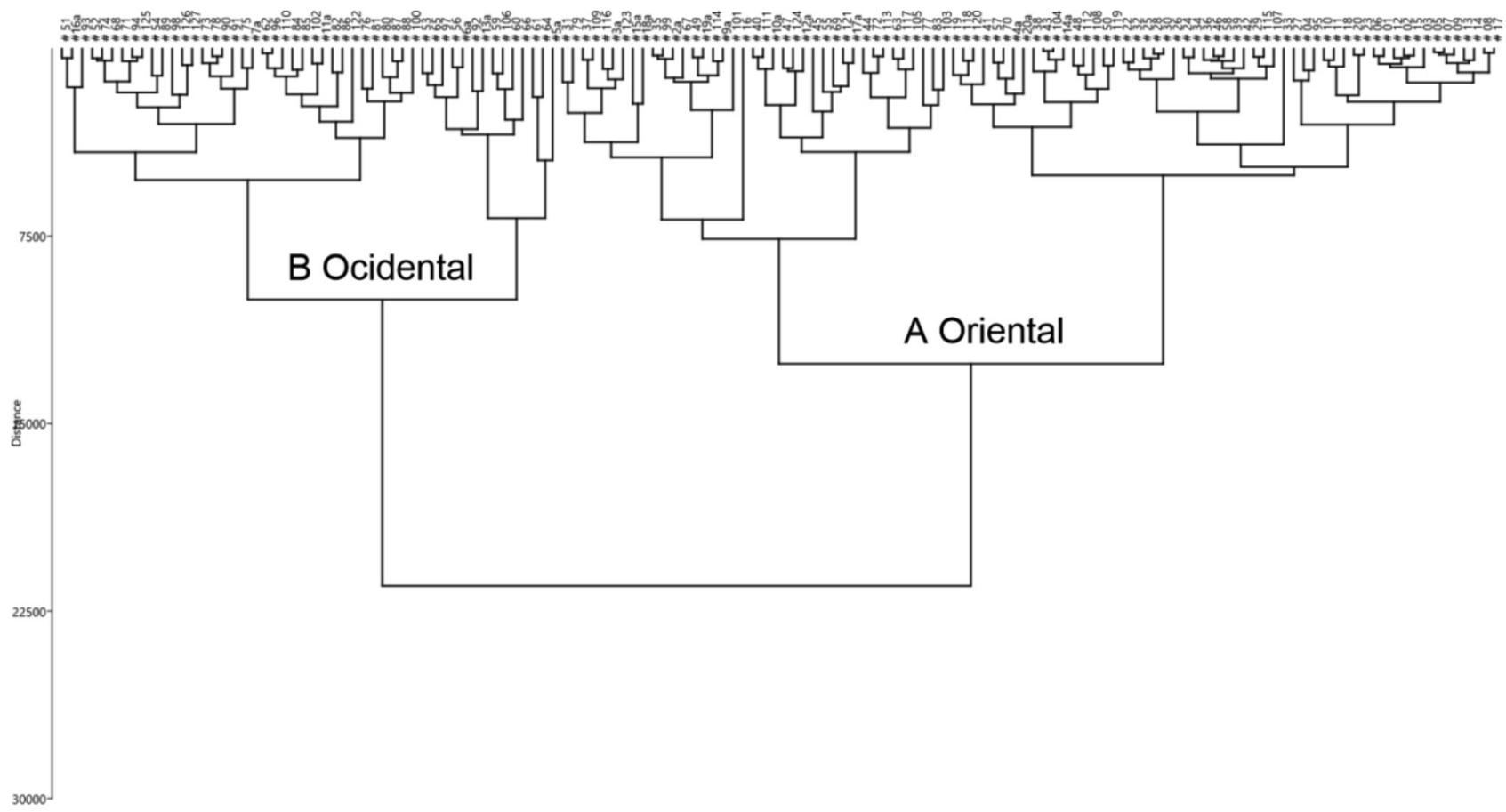

Figure 3. Cluster analysis of selected samples.

The contamination status of the sediment was evaluated in accordance with the sediment quality guidelines established in the Canadian Sediment Quality Guidelines for Protection of Aquatic Life for Marine Sediment (ISQG and PEL) (CCME, 2001). All levels were below PEL (Probable Effect Level), and most levels were below ISQG, with the exceptions of $\mathrm{As}$ (80 samples), $\mathrm{Cu}$ (7 samples) and $\mathrm{Pb}(1$ sample), indicating that the Bertioga Channel presented conditions of a pristine environment. Furthermore, a more detailed analysis using multivariate statistic, indicated that the channel can be divided in two regions, with Largo do Candinho as a frontier with the key condition of low circulation, due to the higher deposition of fine sediments and associated potential contaminated material from the Estuary of Santos and São Vicente.

\section{CONCLUSIONS}

The assessment of trace element and arsenic levels, together with fine particles and TOC content, are important tools for understanding the depositional processes in the Bertioga Channel. Although the levels of the analyzed elements were at or below the established limits of concern, the Bertioga Channel is an important region of Baixada Santista, which has a delicate balance with nearby, important mangroves areas. Expansion plans for the Port complex and associated extensive dredging of the Port channel, in addition to new facilities, indicate a need 


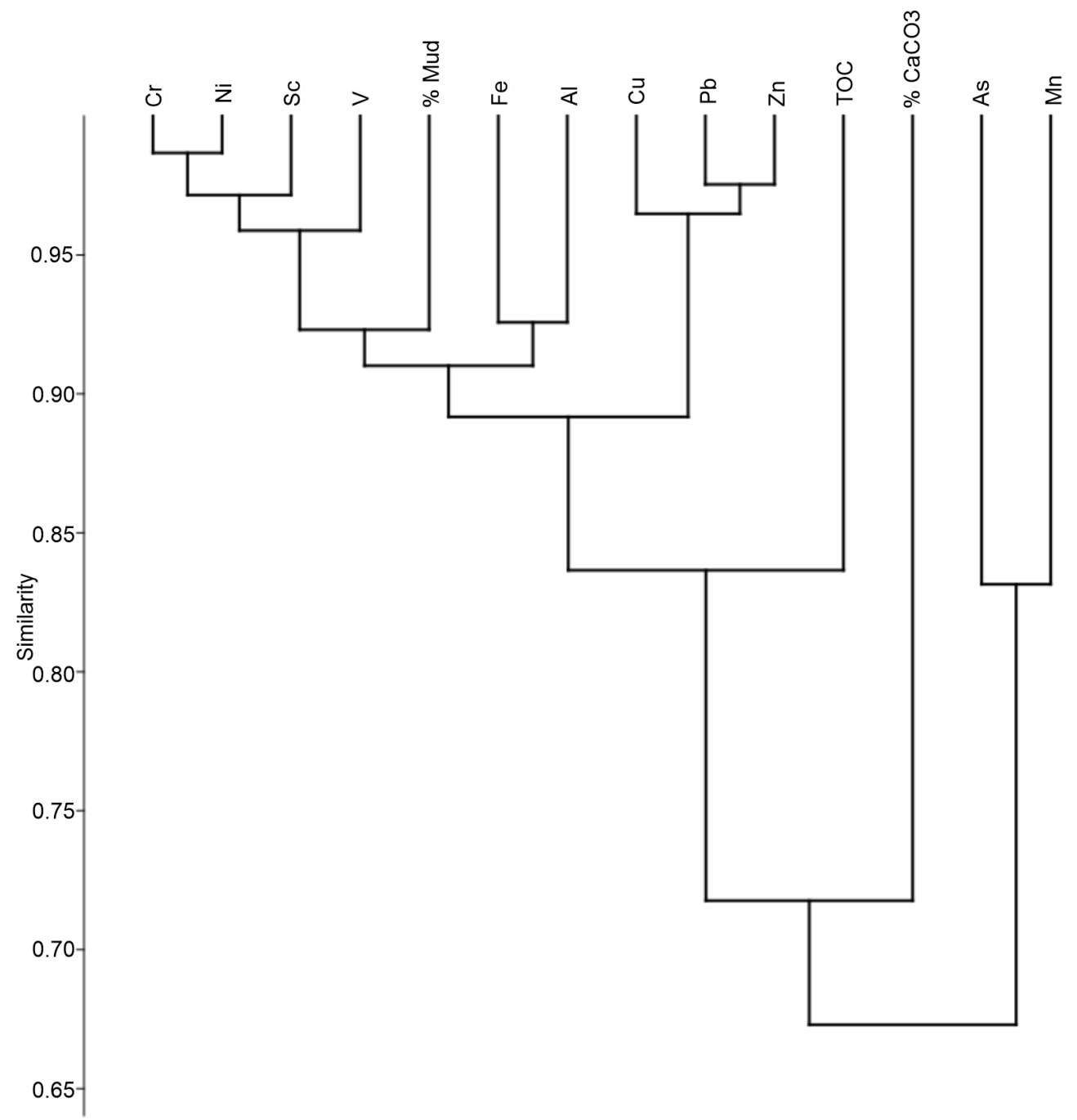

Figure 4. Cluster analysis of the studied variables.

to frequently monitor border regions, particularly the Bertioga Channel, so we can assess changes and potential effect on the existing environmental status. The presence of harbor docks, the disordered occupation and release of domestic effluent without treatment also places the balance of this important system at risk. The database of metals and As levels generated by this work is important, and may help with the coastal and environmental management of this region.

\section{ACKNOWLEDGMENTS}

Thanks to FAPESP (n 2009/01211-0; $n^{\circ}$ 2011/50581-4 and 2017/0898-7) for the financial support.

\section{REFERENCES}

ABDALLAH, M. A. M. 2008. Trace element levels in some commercially valuable fish species from coastal waters of Mediterranean Sea, Egypt. J. Mar. Syst., 73(1-2): 114122. http://dx.doi.org/10.1016/j.jmarsys.2007.09.006

BAPTISTA NETO, J. A., PONZU, V. R. A. \& SICHEL, S. E. 2004. Introdução a Geologia Marinha. Rio de Janeiro: Interciência.

BERBER, G. B. B., AMORIM, E. P., RODRIGUES, M.,
MAHIQUES, M.M., FÁVARO, D. \& BRAGA, E.S. 2007. Distribuição espacial de CNPS e suas relações com metais nos sedimentos superficiais do estuário de Cananéia (SP) - inverno de 2005. XI Congresso Brasileiro de Geoquímica. Anais... Atibaia: 2007

BORDON, I. C. A C., SARKIS, J. E. S., GOBBATO, G. M. HORTELlANI, M. A. \& PEIXOTO, C.M. 2011. Metal concentration in sediments from the Santos Estuarine system: A recent assessment. J. Braz. Chem. Soc., 22(10):1858-1865. http://dx.doi.org/10.1590/S0103-50532011001000005

Buruaem, L. M., CASTRO, Í. B., HORTEllani, M. A., TANIGUCHI, S., FILLMANN, G., SASAKI, S. T., PETTI, M. A. V., SARKIS, J. E. S., BÍCEGO, M. C., MARANHO, L. A., DAVANSO, M. B., NONATO, E. F., CESAR, A., COSTALOTUFO, L. V. \& ABESSA, D. M. S. 2013. Integrated quality assessment of sediments from harbour areas in Santos-São Vicente Estuarine System, Southern Brazil. Estuar. Coast. Shelf. Sci., 130: 179-189. http://dx.doi.org/10.1016/j.ecss.2013.06.006

CCME (Canadian Council of Ministers of the Environment). 2001. Canadian Sediment quality guidelines for the protection of aquatic life: Summary tables. Updated. In: Canadian Environmental Quality Guidelines, 1999. Winnipeg, MB, Canada.

CARVAlHO, A. M.; NETO, A. R. P.\& SANTOS, V. L. C. S. 2005. Distribuição geoquímica de teores de carbonato, carbono orgânico total, lipídeos, hidrocarbonetos (HPAs) e metais pesados nos sedimentos da região oceânica do Rio de Janeiro. 
Revista Virtual, 1(1): 70-84.

CBH-BS (COMITÊ DA BACIA HIDROGRÁFICA DA BAIXADA

SANTISTA). 2011. Relatório de situação: recursos hídricos da Baixada Santista. Disponível em: http://www.sigrh.sp.gov.br/ sigrh/ARQS/RELATORIO/CRH/CBHBS/1573/rs\%202011\%20 cbh-bs\%20versao\%20final.pdf

CESAR, A., CHOUERI, R. B., MORALES-CASELLES, C., PEREIRA, C. D. S., SANTOS, A. R., ABESSA, D. M. S. \& DELVALLS, T. A 2007. Comparative sediment quality assessment in different ecosystems from Spain (Gulf of Cadiz) and Brazil (Santos and São Vicente estuarine system). Rev. Environ. Inter., 33(4): 429-435. 10.1016/j.envint.2006.11.007

CETESB (COMPANHIA DE TECNOLOGIA DE SANEAMENTO AMBIENTAL). 2001. Sistema Estuarino de Santos e São Vicente. Relatório técnico. 178p.

CHOUERI, R. B., CESAR, A., ABESSA, D. M. S., TORRES, R. J., RIBA, I., PEREIRA, C. D. S., NASCIMENTO, M. R. L., MORAIS, R. D., MOZETO, A. A. \& DElvallS, T. A. 2010. Harmonised framework for ecological risk assessment of sediments from ports and estuarine zones of North and South Atlantic. Ecotoxicology, 19(4):678-696. 10.1007/s10646-0090442-y

CODESP (COMPANHIA DOCAS DO ESTADO DE SÃO PAULO). 2011. Porto de Santos: Relatório anual 2011. Disponível em: http://201.33.127.41/down/relatorio/Relatorio2011.pdf

COSTA, E. S., GRILO, C. F., WOLFF, G. A., THOMPSON, A., FIGUEIRA, R. C. L. SÁ, F. \& NETO, R. R. 2016. Geochemical records in sediments of a tropical estuary (Southeastern coast of Brazil). Reg. Stud. Mar. Sci., 6:49-61. http://dx.doi.org/10.1016/j. rsma.2016.03.008

ELKADY, A. A., SWEET, S. T. WADE, T. L. \& KLEIN, A. G. 2015. Distribution and assessment of heavy metals in the aquatic environment of Lake Manzala, Egypt. Ecol. Appl., 58:445-457. 10.1016/j.ecolind.2015.05.029

FORSTNER, U. \&SALOMONS, W. 1980. Trace metals analysis on polluted sediments. Part I: Assessment of sources and intensities. Environ. Technol. Lett., 1: 495-505.

FÚlFARO, V. J. \& PONÇANO, W. L. 1976. Sedimentação atual do estuário e Baía de Santos: um modelo geológico aplicado a projetos de expansão da zona portuária. In: Congresso Brasileiro de Geologia de engenharia. Rio de Janeiro, 2:67-90.

FUKUE, M., YANAI, M., SATO, Y., FUJIKAWA, T., KURUKAWA, Y. \& TANI, S. 2006. Background values for evaluation of heavy metal contamination in sediments. J. Hazard. Mater., 136(SI1):111-119. 10.1016/j.jhazmat.2005.11.020

GOHER, M. E., HASSAN, A. M., ABDEL-MONIEM, I. A., FAHMY, A. H. \& EL-SAYED, S. M. 2014. Evaluation of surface water quality and heavy metal indices of Ismailia Canal, Nile River, Egypt. Egypt. J. Aquat. Res., 40(3):225-233. http:// dx.doi.org/10.1016/j.ejar.2014.09.001

GONÇALVES, C., FIGUEIRA, R. C. L., SARTORETTO, J. R., SAlAROLI, A. B., RIBEIRO, A. P., FERREIRA, P. A. L. \& MAHIQUES, M. M. 2013. Reconstruction of historical trends in potentially toxic elements from sediment cores collected in Bertioga Channel, southeastern Brazil. Brazilian J. Oceanogr., 61(2): 149-160. 10.1590/S1679-87592013000200007

ISLAM, M. S., AHMED, M. K., RAKNUZZAMAN, M., MANUN, M. H. \& ISLAM, M. K. 2015. Heavy metal pollution in surface water and sediment: A preliminary assessment of an urban river in a developing country. Ecol. Indic., 48: 282-291. 10.1016/j. ecolind.2014.08.016

JAKIMSKA, A., KONIECZKA, P., SKÓRA, K., NAMIESNIK, J. 2011. Bioaccumulation of metals in tissues marine animals, part I: the role and impact of heavy metals on organisms. Pol. J.
Environ. Stud., 20(5), 117-1125. Available in: http://www.pjoes. com/abstracts/2011/Vol20/No05/01.html

KARADEDE-AKIN, H. \& ÜNLÜ, E. 2007. Heavy metal concentrations in water, sediment, fish and some benthic organisms from Tigris River, Turkey. Environ. Monit. Assess., 131(1-3): 323-337.

KIM, B. S. M., SALAROLI, A. B., FERREIRA, P. A. L., SARTORETTO, J. R., MAHIQUES, M. M. \& FIGUEIRA, R. C. L. 2016. Spatial distribution and enrichment assessment of heavy metals in surface sediments from Baixada Santista, Southeastern Brazil. Mar. Pollut. Bull., 103:333-338. http:// dx.doi.org/10.1016/j.marpolbul.2015.12.041

KIM, B. S. M., ANGELI, J. L. F., FERREIRA, P. A. L., SARTORETTO, J. R., MIYOSHI, C., MAHIQUES, M. M. \& FIGUEIRA, R. C. L. 2017. Use of a chemometric tool to establish the regional background and assess trace metal enrichment at Baixada Santista - southeastern Brazil. Chemosphere, 166:372379. http://dx.doi.org/10.1016/j.chemosphere.2016.09.132

KIM, B. S. M., BÍCEGO, M. C., TANIGUCHI, S., SIEGLE, E., OLIVEIRA, R., ALCÁNTARA-CARRIÓ, J., FIGUEIRA, R. C. L. 2018. Organic and inorganic contamination in sediments from Araçá Bay, São Sebastião, Brazil. Ocean Coast. Manag., In Press. https://doi.org/10.1016/j.ocecoaman.2017.12.028

KJERFVE, B. \& MAGILL, K. E. 1989. Geographic and hydrodynamic characteristics of shallow coastal lagoons. Mar. Geol., 88(3-4): 187-199.

MACHADO, W., SILVA-FILHO, E. V., OLIVEIRA, R. R. \& LACERDA, L. D. 2002. Trace metal retention in mangrove ecosystems in Guanabara Bay, SE Brazil. Mar. Pollut. Bull., 44:1277-1280

MIRANDA, L. B. \& CASTRO, B. M. 1991. Condições oceanográficas no Canal de Bertioga. Relatório Técnico. Fundação de Estudos e Pesquisas Aquáticas (FUNDESPA).

MIRANDA, L. B.; CASTRO, B. M.\& KJERFVE, B. 2002. Princípios de oceanografia física de estuários. São Paulo: Edusp.

MIRLEAN, P., MEDEANIC, S., GARCIA, F. A., TRAVASSOS, M. P. \& BAISCH, P. 2012. Arsenic enrichment in shelf and coastal sediment of the Brazilian subtropics. Cont. Shelf. Res., 35:129-136. http://dx.doi.org/10.1016/j.csr.2012.01.006.

OLIVEIRA, M. L. J.; OTERO, X. L. \& FERREIRA, J. F. 2005. Mercúrio total em solos de manguezais da Baixada Santista e Ilha do Cardoso, Estado de São Paulo. Quim. Nova, 30(3):519-524.

REIMANN, C., MATSCHULLAT, J., BIRKE, M. \& SALMINEN, R. 2009. Arsenic distribution in the environment: The effects of scale. Appl. Geochemistry, 24(7):1147-1167.

ROMERO, F. M., ARMIENTA, M. A. \& CARRILLO-CHAVEZ, A. 2004. Arsenic sorption by carbonate-rich aquifer material, a control on arsenic mobility at Zimapán, México. Arch. Environ. Contam. Toxicol., 47(1):1-13.

SÁ, F., MACHADO, E. C., ANGUlO, R. J., VEIGA, F. A. \& BRANDINI, N. 2006. Arsenic and Heavy metals in Sediments near Paranaguá Port , Southern Brazil. J. Coast. Res., 39(SI39):1066-1068.

SCHAEFFER-NOVELLI, Y. 1986. Barcaça Gisela. Avaliação de impacto ambiental. Baixada Santista. São Paulo, Brasil: 135p.

SIQUEIRA, G. W., BRAGA, E. S., PEREIRA, S. F. P. \& SILVA, E. 2005. Distribuição do mercúrio em sedimentos de fundo no Estuário de Santos SP/Brasil. Rem-Rev. Esc. Minas, 58(4):309-316.

SONG, Y., CHOI, M. S., LEE, J. Y. \& JANG, D. J. 2014. Regional background concentrations of heavy metals $(\mathrm{Cr}, \mathrm{Ci}, \mathrm{Ni}, \mathrm{Cu}$, $\mathrm{Zn}, \mathrm{Pb})$ in coastal sediments of the South Sea of Korea. Sci. Total Environ., 482-483:80-91. http://dx.doi.org/10.1016/ j.scitotenv.2014.02.068.

TAKAMATSU, T., KAWASHIMA, M. \& KOYAMA, M. 1985. The 
role of $\mathrm{Mn}^{2+}$ - rich hydrous manganese oxide in the accumulation of arsenic in lake sediments. Water Res., 19:1029-1032.

TRAMONTE, K. M., FIGUEIRA, R. C. L., FERREIRA, P. A. L., RIBEIRO, A. P., BATISTA, M. F. \& MAHIQUES, M. M. 2016. Environmental availability of potentially toxic elements in estuarine sediments of the Cananéia-Iguape coastal system, Southeastern Brazil. Mar. Pollut. Bull., 103(1-2):206-269. http:// dx.doi.org/10.1016/j.marpolbul.2015.12.011

USEPA (Environmental Protection Agency). 1996. Method 3050B.
Acid digestion of sediments, sludges, and soils. Revision 2. December, 1996.

USEPA (Environmental Protection Agency). 2007. Method 6010C. Inductively coupled plasma-atomic emission spectrometry. Revision 3. 2007.

WANG, J., LIU, G., LU, L., ZHANG, J. \& LIU, H. 2015. Geochemical normalization and assessment of heavy metals $(\mathrm{Cu}, \mathrm{Pb}, \mathrm{Zn}$ and Ni) in sediments from the Huaihe River, Ahhui, China. Catena, 129:30-38. http://dx.doi.org/10.1016/j.catena.2015.02.008. 